(C) 2017 by the Arizona Board of Regents on behalf of the University of Arizona. This is an Open Access article, distributed under the terms of the Creative Commons Attribution-NonCommercial-NoDerivatives licence (http://creativecommons.org/licenses/by-nc-nd/4.0/), which permits non-commercial re-use, distribution, and reproduction in any medium, provided the original work is unaltered and is properly cited. The written permission of Cambridge University Press must be obtained for commercial re-use or in order to create a derivative work.

\title{
RADIOCARBON CONSTRAINTS ON THE AGE OF THE WORLD'S HIGHEST-ELEVATION CAVE-BEAR POPULATION, CONTURINES CAVE (DOLOMITES, NORTHERN ITALY)
}

\author{
Christoph Spötl ${ }^{1 *} \cdot$ Paula $\mathbf{J}$ Reimer ${ }^{2} \cdot$ Gernot Rabeder $^{3} \cdot$ Christopher Bronk Ramsey $^{4}$ \\ ${ }^{1}$ Institut für Geologie, Leopold-Franzens-Universität Innsbruck, Innrain 52, 6020 Innsbruck, Austria. \\ ${ }^{2}$ Centre for Climate, the Environment and Chronology (14CHRONO), School of Natural and Built Environment, \\ Queen's University Belfast, Belfast BT7 1NN, United Kingdom. \\ ${ }^{3}$ Institut für Paläontologie, Universität Wien, Althanstraße 14, 1090 Vienna, Austria. \\ ${ }^{4}$ Oxford Radiocarbon Accelerator Unit Research Laboratory for Archaeology, South Parks Road, Oxford OX1 \\ 3QY, United Kindom.
}

\begin{abstract}
We report radiocarbon $\left({ }^{14} \mathrm{C}\right)$ dates on bone samples of Ursus ladinicus, a small cave bear species well adapted to a life in the mountains, whose remains were found in Conturines Cave. Located at $2775 \mathrm{~m}$ asl in the Dolomites of northern Italy, this cave is by far the highest known cave bear site worldwide. Eleven ${ }^{14} \mathrm{C}$ dates obtained by the Belfast and Oxford laboratories on samples showing good collagen preservation yielded consistent ages in excess of 46-50 ka BP. These results show that contrary to the previously held view these cave bear remains are older than Marine Isotope Stage 3, and likely date from a warm climate period with a high treeline, possibly the Last Interglacial.
\end{abstract}

KEYWORDS: Alps, cave bear, paleoclimate, radiocarbon dating.

\section{INTRODUCTION}

The cave bear was a prominent member of the Late Pleistocene megafauna in Europe and western Asia and became extinct around 28-25 cal ka BP (Pacher and Stuart 2009; Baca et al. 2016). The majority of remains were found in caves where this mammal probably died during winter hibernation. Dozens of caves containing bones and teeth of cave bear are known from the Alps from the valleys up to the high mountains. Genetic research has shown that four different subspecies (or species) were present in this mountain range (Hofreiter et al. 2002, 2004). Ursus ladinicus (Rabeder et al. 2004) was one of them and its small body size, slender extremities, and distinct dentition (especially the higher evolution level of lower $\mathrm{m} 2$ ) have been attributed to adaptations to a life upon the mountains (Rabeder et al. 2004, 2008).

The chronology of cave bears is almost exclusively based on radiocarbon $\left({ }^{14} \mathrm{C}\right)$ dates of bones produced over several decades by a variety of laboratories. Pacher and Stuart (2009) reassessed the available data and concluded that cave bears were present in the Alps and its foreland during Marine Isotope Stage (MIS) 3-also known as Middle Würmian in the Alpine Quaternary stratigraphy (Preusser 2004; Heiri et al. 2014) - but several dates were close to or older than the limit of ${ }^{14} \mathrm{C}$ dating. Very little chronological information is currently available prior to about $50 \mathrm{ka}$ because speleothems (which could be dated using U/Th far beyond $50 \mathrm{ka}$ ) are rarely interlayered with clastic sediments containing cave bear remains. In the past, U/Th dating of bone material from alpine caves was attempted using alpha-spectrometry (Leitner-Wild and Steffan 1993; Leitner-Wild et al. 1994), yielded large uncertainties and is regarded as problematic as bones are known to be open systems to U (e.g., Pike et al. 2002; Sambridge et al. 2012).

\footnotetext{
*Corresponding author. Email: christoph.spoetl@uibk.ac.at.
} 
Several of the caves occupied by the cave bear in the Alps during the last glacial period are located close to the modern (natural) treeline. The complex internal stratigraphy of the cave sediments and the precision of the ${ }^{14} \mathrm{C}$ dates do not allow to conclusively answer the question whether the cave bear used individual alpine sites continuously throughout MIS 3 (an interval of large climate shifts) or only during some intervals, e.g. major interstadials. Starting about $40 \mathrm{ka}$ ago, the data indicate a gradual disappearance of this animal from these alpine sites and about 5 ka later also from lower-elevation caves (Rabeder and Frischauf 2016), suggesting a general climate control.

A special case in this context is Conturines Cave in the Dolomites of northern Italy, which is the highest site used by cave bears in the Alps, topping other alpine caves by several hundred meters. It ranks as the world's highest-elevation cave containing remains of the cave bear. Located in a barren landscape today, the presence of this herbivore cave bear population raised serious questions about the paleovegetation and paleoclimate as initial ${ }^{14} \mathrm{C}$ dates suggested an MIS 3 age of this fauna (Rabeder 1991; Hofreiter et al. 2004). Here, we report new dates obtained by two different laboratories, which indicate that these remains are in fact older than the ${ }^{14} \mathrm{C}$ dating limit and that they therefore have no implications for the paleoenvironment and paleoclimate during MIS 3.

\section{SETTING}

Conturines Cave (Ander dles Cunturines in the local Ladin language) is located $4 \mathrm{~km}$ east of St. Kassian (San Ciascian, San Cassiano) in the Dolomites of northern Italy. The entrance opens at an elevation of $2775 \mathrm{~m}$ asl at the upper end of an east-facing cirque (Figure 1). The cave is about $160 \mathrm{~m}$ long and comprises a single ascending conduit, on average about $8 \mathrm{~m}$ in diameter. Breakdown blocks dominate the character of this cave and a bird guano deposit is present behind the entrance. The inner part also contains large dripstone formations including a several-meter-thick flowstone. These carbonate deposits are inactive and show strong signs of corrosion. No active speleothem deposition occurs in the cave reflecting the high elevation and the lack of a soil-covered catchment of the cave's drip water.

Remains of Ursus ladinicus were found at the end of the ascending passage some $110 \mathrm{~m}$ behind the entrance (Figure 1). In this so-called Schädelhalle (Skull Chamber) up to $0.5 \mathrm{~m}$ of unconsolidated sediments rest on a thick flowstone. A thin and discontinuous layer of unfossiliferous dolomitic sand forms the base of this sediment package. This sand is unconformably overlain by the main fossil-bearing layer, consisting of yellowish-grey dolomite sand and numerous angular dolomite blocks. Intact and fragmented bones as well as teeth were dispersed in this layer. These remains have been redeposited by running water and are mixed with the coarse clastic sediment (Rabeder 1991). Later on, small cave streams partly eroded this fossiliferous layer, exhumed some of the bones and skulls, and sand devoid of fossil remains was locally deposited in these channels.

In addition to cave bear bones and teeth (showing a high percentage of juvenile individuals), two bone fragments (a juvenile mandible and a maxillary fragment from the same individual) of a cave lion were found (Rabeder 1991).

The fact that the Skull Chamber lies about $58 \mathrm{~m}$ higher than the entrance results in a slight thermal anomaly of the interior of the cave of about $+1.5^{\circ} \mathrm{C}$ instead of about $-1.0^{\circ} \mathrm{C}$ as expected from the mean annual air temperature outside the cave at this altitude. The cave has undergone some minor changes since the time the cave bear used this site for hibernation (including partial 


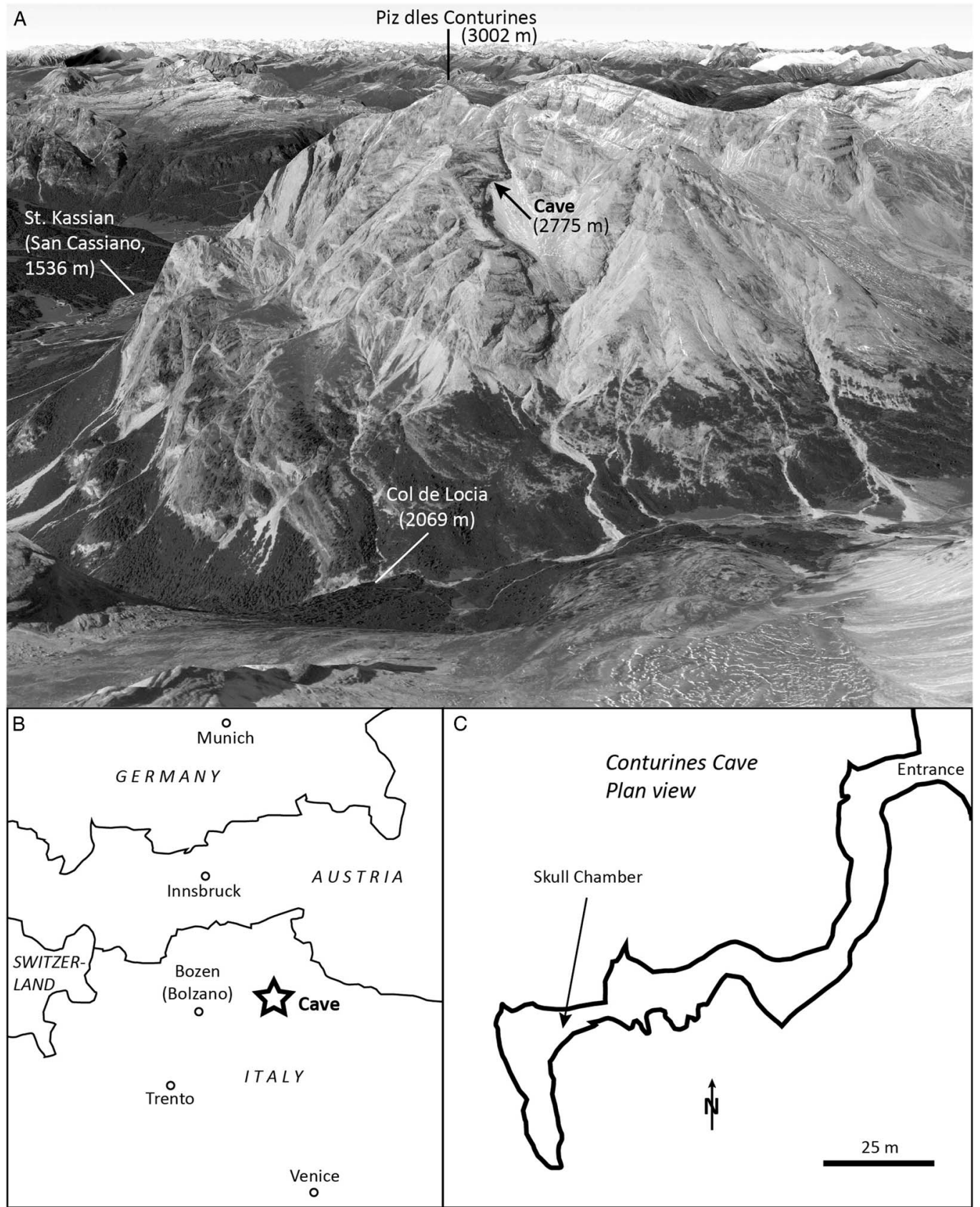

Figure 1 (A) Oblique view towards northwest of the Conturines massif and location of the cave entrance (Google Earth Pro image); (B) site map; (C) simplified map of Conturines Cave and the Skull Chamber where the cave bear bones were excavated.

collapse of the ceiling in the hall just behind the Skull Chamber). However, the basic geometry of the cave - the lack of an upper entrance and hence the positive thermal anomaly in the interior - very likely has not changed since then and apparently allowed this animal to survive the harsh winter in the high mountains. 
Table $1 \mathrm{~N}$ content of whole bones and atomic $\mathrm{C} / \mathrm{N}$ ratio, radiocarbon and stable $\mathrm{C}$ and $\mathrm{N}$ isotope data of extracted collagen from Conturines Cave bear bones.

\begin{tabular}{|c|c|c|c|c|c|c|c|c|c|}
\hline Sample ID & Element & $\% \mathrm{~N}$ & $\begin{array}{l}\text { Belfast } \\
\text { lab code }\end{array}$ & $\begin{array}{l}{ }^{14} \mathrm{C} \text { age } \\
\text { BP }\end{array}$ & $\begin{array}{l}\delta^{13} \mathrm{C} \\
(\% \circ)\end{array}$ & $\begin{array}{l}\delta^{15} \mathrm{~N} \\
(\% \circ)\end{array}$ & $\mathrm{C} / \mathrm{N}$ & $\begin{array}{l}\text { Oxford } \\
\text { lab code }\end{array}$ & $\begin{array}{l}{ }^{14} \mathrm{C} \text { age } \\
\mathrm{BP}\end{array}$ \\
\hline $\mathrm{Cu} 1$ & Mc3 dex. & 3.3 & UBA-27630 & $>46,435$ & -22.2 & -0.2 & 3.24 & OxA-35204 & $>47,200$ \\
\hline Cu661-3 & Phal. med. & 3.8 & UBA-27631 & $>47,459$ & -22.6 & -0.5 & 3.22 & & \\
\hline Cu669-1 & Mc4 sin. & 3.6 & UBA-27632 & $>48,821$ & -22.0 & -0.2 & 3.23 & OxA-35178 & $>50,500$ \\
\hline $\mathrm{Cu} 31$ & Mt3 dex. & 3.4 & UBA-27633 & $>46,216$ & -22.9 & 0.2 & 3.23 & OxA-35203 & $>50,200$ \\
\hline Cu661-1 & Mc3 dex. & 3.5 & UBA-27634 & $>48,984$ & -22.6 & -0.4 & 3.22 & OxA-35179 & $>50,300$ \\
\hline $\mathrm{Cu} 4-3$ & Ph. mes. in & 4.1 & UBA & $>50,579$ & -21.5 & 0.0 & 3.20 & & \\
\hline Cu648 & Mt1 sin. & 3.5 & UBA & $>48,352$ & -22.0 & -0.4 & 3.20 & & \\
\hline Cu648-1 & Metapodium fragm. & 3.4 & UBA-27637 & $>50,579$ & -22.1 & 0.4 & 3.22 & & \\
\hline $\mathrm{Cu} 861$ & $\mathrm{Ph}$. bas. Indet. & 3.6 & UBA-27638 & $>49,611$ & -22.3 & -0.6 & 3.21 & & \\
\hline $\mathrm{Cu} 822$ & Mt3 dex. & 4.0 & UBA-27639 & $>50,071$ & -21.6 & -0.5 & 3.19 & OxA-35180 & $>50,400$ \\
\hline Cu650 & Pelvis fragm. & 3.5 & UBA-27640 & $>50,579$ & -23.1 & 3.0 & 3.21 & & \\
\hline
\end{tabular}

\section{SAMPLES AND METHODS}

Twenty-five randomly selected small cave bear bones (metapodials and phalanges) and one pelvis fragment (Table 1) excavated from the coarse-grained fossiliferous layer in the Skull Chamber were prescreened for their whole bone nitrogen content. Collagen extraction was performed on 11 samples showing values between 3.3 and $4.1 \%$ N. Collagen was extracted from cleaned, crushed bone samples with an acid-base-acid treatment followed by gelatinization and ultrafiltration (Brock et al. 2010) using a Vivaspin ${ }^{\circledR}$ filter cleaning method introduced by Bronk Ramsey et al. (2004a). The collagen was then freeze-dried. The dried samples were weighed into precombusted quartz tubes with an excess of copper oxide $(\mathrm{CuO})$, sealed under vacuum and combusted to carbon dioxide $\left(\mathrm{CO}_{2}\right)$. The $\mathrm{CO}_{2}$ was converted to graphite on an iron catalyst using the zinc reduction method (Slota et al. 1987). The ${ }^{14} \mathrm{C} /{ }^{12} \mathrm{C}$ and ${ }^{13} \mathrm{C} /{ }^{12} \mathrm{C}$ ratios were measured by accelerator mass spectrometry (AMS) at ${ }^{14} \mathrm{CHRONO}$, Queen's University Belfast. The sample ${ }^{14} \mathrm{C} /{ }^{12} \mathrm{C}$ ratio was background-corrected using measurements on collagen extracted from the Latton mammoth bone (Lewis et al. 2006) and normalized to the HOXII standard (SRM 4990C; National Institute of Standards and Technology). The ${ }^{14} \mathrm{C} /{ }^{12} \mathrm{C}$ ratios were corrected for isotope fractionation using the AMS measured $\delta^{13} \mathrm{C}$ which accounts for both natural and machine fractionation. The ${ }^{14} \mathrm{C}$ age and one standard deviation were calculated using the Libby half-life of $5568 \mathrm{yr}$ following the methods of Stuiver and Polach (1977). Stable isotopes $\left(\delta^{13} \mathrm{C}\right.$ and $\left.\delta^{15} \mathrm{~N}\right), \%$ carbon and $\%$ nitrogen were measured on a Delta V Advantage with a Flash elemental analyzer. Stable isotope standards IA-R041 L-Alanine, IAEA-N-2 Ammonium Sulphate and IAEA-CH-Sucrose were analyzed with the unknown samples to provide a two-point calibration. An internal fishbone collagen sample was also analyzed). Reproducibility for ultrafiltered bone collagen is $0.22 \%$ or $\delta^{13} \mathrm{C}$ and $0.15 \%$ o for $\delta^{15} \mathrm{~N}$.

Aliquots of five of these bone samples were also analyzed in the Oxford Radiocarbon Accelerator Unit Research Laboratory for Archaeology using the ultrafiltration method outlined in Brock et al. (2010), and the ultra-filter cleaning method introduced by Bronk Ramsey et al. (2004a). The samples were combusted in a $\mathrm{CHN}$ analyzer yielding $\mathrm{C} / \mathrm{N}$ ratios in the range 3.13-3.20. As part of the pretreatment process, carbon isotope measurements were measured on an Sercon mass spectrometer against an alanine standard with a precision of $\pm 0.3 \%$ relative to VPDB. The samples were graphitized using the method outlined in Dee and Bronk Ramsey 
(2000) and measured in an HVEE Tandetron AMS as described in Bronk Ramsey et al. (2004b). In this study, all of the measurements made at Oxford were indistinguishable from background.

\section{RESULTS}

The 25 prescreened bone samples showed N-contents between 2.0 and $4.1 \% \mathrm{~N}$ (one sample yielded $1.2 \%$ ), suggesting good preservation of collagen. This was confirmed by measurements of the atomic $\mathrm{C} / \mathrm{N}$ ratio on the extracted collagen (3.1-3.2; Table 1), which falls within the acceptable range (2.9-3.6) for the bones (DeNiro 1985; van Klinken 1999).

Radiocarbon dates obtained on 11 samples with the highest $\mathrm{N}$ values yielded infinite ages in the Belfast laboratory. This was confirmed by analyses carried out in the Oxford laboratory (Table 1 ). $\delta^{13} \mathrm{C}$ and $\delta^{15} \mathrm{~N}$ values range from -23.2 to $-21.5 \%$ and from -0.6 to $+2.9 \%$ (Table 1 ).

\section{DISCUSSION}

The new ${ }^{14} \mathrm{C}$ data consistently show that cave bear hibernated and died in the interior of Conturines Cave prior to ca. $50 \mathrm{ka}$. The new data are regarded as reliable given the good state of collagen preservation (facilitated by the cold environment) and the independent confirmation by two laboratories. Random sampling for dating is regarded as a reasonable approach in such a setting which lacks a well-stratified sedimentary succession and suggests local reworking of the bones.

Hofreiter et al. $(2002,2004)$ reported a single AMS date of $44.3 \pm 0.9 \mathrm{ka}$ (determined by Beta Analytics) from Conturines Cave. Unfortunately, no analytical details were published. Given the progress in preparation and analysis of old bone material in the past two decades this finite date should not be regarded as a contradiction to the new data set. In their review of ${ }^{14} \mathrm{C}$ dating of Pleistocene bone material van der Plicht and Palstra (2016:250) stress that "fossil bones with reported ages older than 45,000 BP must be considered with great care." The new dates are consistent with earlier attempts to constrain the age of the Conturines samples using U-series dating. These dates ( $87 \pm 5 \mathrm{ka} \mathrm{BP}$ and $108+8 /-7 \mathrm{ka} \mathrm{BP})$, however, were only briefly mentioned but never properly published (Rosendahl et al. 2007; Döppes and Rosendahl 2009) and it is difficult to judge their validity given that bones are known to readily exchange $\mathrm{U}$ with the surrounding environment (e.g., Pike et al. 2002, 2005).

The infinite ${ }^{14} \mathrm{C}$ dates are minimum age estimates and it is currently not possible to convert them into minimum calendar ages.

The former presence of cave bears at this altitude is surprising given the almost complete lack of vegetation near the cave site. The modern treeline is located at about $2000-2100 \mathrm{~m}$ asl in the Dolomites, i.e. about 700-800 m below the cave (Peer 1980). No other high-elevation cave bear sites are currently known from the Dolomites and it is instructive to take a look at the large database obtained from caves in the Northern Calcareous Alps of Austria. Chronological data from this mountain range — biased by the ${ }^{14} \mathrm{C}$ method (i.e. to less than about $50 \mathrm{ka}$ ) - indicate that cave bears used these mountain caves during MIS 3 (e.g., Hofreiter et al. 2004; Döppes et al. 2011; Rabeder and Frischauf 2016). These sites are on average 500-1400 m lower in elevation and partly close to or below the modern treeline. These bear remains therefore indicate climatically benign and certainly ice-free conditions during MIS 3 in Europe, a time interval characterized by high-frequency, high-amplitude shifts in temperature (e.g., Genty et al. 2003; Wohlfart et al. 2008; Heiri et al. 2014; Fankhauser et al. 2016). Closed forests had 
disappeared from the Alps and their northern foreland already at the end of MIS 5a (DrescherSchneider 2000; Müller et al. 2003). Available proxy records from the Alps covering parts of MIS 3 indicate an Arctic tundra vegetation even in the lowlands (Bortenschlager and Bortenschlager 1978) interrupted by intervals of milder conditions during some larger interstadials (Jost-Stauffer et al. 2005; Drescher-Schneider et al. 2007; Tütken et al. 2007; Starnberger et al. 2013). Even during the pronounced Greenland Interstadial 14, whose maximum lasted from 54.2 to $51.7 \mathrm{ka}$, glaciers in the Eastern Alps were most likely larger than during the maximum of the Little Ice Age, as shown by speleothem data (Spötl et al. 2006). During intervening stadials (including Heinrich events) temperatures dropped drastically and loess sections in the foreland close to the Eastern Alps show evidence of permafrost (Terhorst et al. 2011; Thiel et al. 2011; Nigst et al. 2014). The level of precision of the available ${ }^{14} \mathrm{C}$ data from the Northern Calcareous Alps does not permit to unequivocally relate alpine cave bear data to the climate history e.g. known from Greenland ice cores and alpine speleothems (e.g., Svensson et al. 2008; Moseley et al. 2014). It is likely, however, that (high) alpine sites were occupied only during pronounced interstadials and it is tempting to speculate that the high abundance of cave bear remains in at least some of these sites reflects high mortality during hibernation at the end of these milder intervals. In contrast, data from low-lying cave sites such as Tischoferhöhle in Tyrol (594 $\mathrm{m}$ asl) suggest that these warmer caves were also used by the cave bear during stadials, e.g. the two stadials preceding and following Greenland Interstadial 8 (Spötl et al. 2014).

The new ${ }^{14} \mathrm{C}$ data from Conturines Cave strongly suggest that this extreme site was used by Ursus ladinicus prior to MIS 3, possibly during the Last Interglacial or, less likely, during the First or Second Early Würmian Interstadial (MIS 5c and 5a, respectively). During these times the treeline was likely up to a few hundred meters higher (Last Interglacial) respectively lower (Early Würmian Interstadials) than today, but still lower than the cave site. Rather than claiming an extreme treeline rise up to the elevation of the cave (e.g., Rabeder 1991) we attribute the survival of this population to the adaptation of the small Ursus ladinicus to steep mountainous environments at the very edge of their ecological niche. This is supported by the stable isotope composition of its bones, which yielded record-low $\delta^{13} \mathrm{C}$ values and among the lowest $\delta^{15} \mathrm{~N}$ values of all European cave bear samples (Bocherens 2015; Krajcarz et al. 2016). These studies show that $\delta^{13} \mathrm{C}$ of collagen scales inversely with altitude and our data (Table 1) confirm the published data of Conturines bone samples (Fernández-Mosquera et al. 2001; Horacek et al. 2012). These two previous studies also reported $\delta^{15} \mathrm{~N}$ values between +0.3 and $+2.1 \%$, which are somewhat higher than those of our samples $(-0.6$ to $+0.4 \%$, one value of $+2.9 \%$, see Table 1). The data do support, however, the previously recognized deviation of the Conturines samples from a general trend of decreasing cave bear $\delta^{15} \mathrm{~N}$ values with increasing altitude. This was attributed to different altitudes of feeding and hibernating of Ursus ladinicus at this extreme site in the Dolomites (Bocherens 2015; Krajcarz et al. 2016).

\section{CONCLUDING REMARKS}

The new ${ }^{14} \mathrm{C}$ analyses help to resolve a long-standing conundrum showing that these cave bear remains carry no implications for the MIS 3 paleoclimate in the Alps. In the absence of speleothems associated with these remains further refinement of these infinite ${ }^{14} \mathrm{C}$ dates will be challenging.

This study in conjunction with others performed on old bone material (e.g. Plicht and Palstra 2016) emphasize that previous age assignments and interpretations of alpine cave bear dates close to the upper limit of ${ }^{14} \mathrm{C}$ dating require a reassessment. Examples include two dates 
from Brieglersberghöhle (Totes Gebirge, $1960 \mathrm{~m}$ asl; Rabeder et al. 2005), which yielded $50,700+4200 /-2700$ and $48,700+3200 /-2300$, an age of 48,740 \pm 800 BP from Bärenfalle (Tennengebirge, $2100 \mathrm{~m}$ asl; Frischauf et al. 2015) and an age of 50,800+4300/-2800 BP from Gauerblickhöhle (Sulzfluh, $2305 \mathrm{~m}$ asl). The latter sample was subsequently reanalyzed following ultrafiltration and the resulting age was $>52,600 \mathrm{BP}$ (Büchel et al. 2014). Ages beyond some $45 \mathrm{ka} \mathrm{BP}$ are extremely sensitive to contamination by modern carbon and issues related to the blank become very important.

\section{ACKNOWLEDGMENTS}

The ongoing research on Conturines Cave is carried out with permission from the Naturpark Fanes-Sennes-Prags and we are particularly grateful to G Nagler for this continuous support. Part of the work received funding from the Autonomous Province of Bozen-Südtirol. We appreciate the thoughtful comments by M Robu and an anonymous reviewer.

\section{REFERENCES}

Baca M, Popović D, Stefaniak K, Marciszak A, Urbanowski M, Nadachowski A, Mackiewicz P. 2016. Retreat and extinction of the Late Pleistocene cave bear (Ursus spelaeus sensu lato). Science of Nature 103:92. DOI 10.1007/s00114-016-1414-8.

Bocherens H. 2015. Isotopic tracking of large carnivore palaeoecology in the mammoth steppe. Quaternary Science Reviews 117:42-71.

Bortenschlager I, Bortenschlager S. 1978. Pollenanalytische Untersuchung am Bänderton von Baumkirchen (Inntal, Tirol). Zeitschrift für Gletscherkunde und Glazialgeologie 14:95-103.

Brock F, Higham T, Ditchfield P, Ramsey CB. 2010. Current pretreatment methods for AMS radiocarbon dating at the Oxford Radiocarbon Accelerator Unit (ORAU). Radiocarbon 52(1): 103-12.

Bronk Ramsey C, Higham T, Bowles A, Hedges R. 2004a. Improvements to the pretreatment of bone at Oxford. Radiocarbon 46(1):155-63.

Bronk Ramsey C, Higham TFG, Leach P. 2004b. Towards high-precision AMS: Progress and limitations. Radiocarbon 46(1):17-24.

Büchel E, Laughlan L, Rabeder G. 2014. Höhlenbären in Vorarlberg. Jahrbuch des Vorarlberger Landesmuseumsvereins 2014:8-37.

Dee M, Bronk Ramsey C. 2000. Refinement of graphite target production at ORAU. Nuclear Instruments and Methods in Physics Research B172(1-4):449-53.

DeNiro MJ. 1985. Postmortem preservation and alteration of in vivo bone collagen isotope ratios in relation to palaeodietary reconstruction. Nature 317:806-9.

Döppes D, Rosendahl W. 2009. Numerically dated palaeontological cave sites of Alpine region from Late Middle Pleistocene to Early Late Pleistocene. Preistoria Alpina 44:45-8.

Döppes D, Stiller M, Rabeder G. 2011. Was the Middle Würmian in the High Alps warmer than today? Quaternary International 245: 193-200.
Drescher-Schneider R. 2000. Die Vegetations- und Klimaentwicklung im Riß/Würm-Interglazial und im Früh- und Mittelwürm in der Umgebung von Mondsee. Ergebnisse der pollenanalytischen Untersuchungen. In: Klimaentwicklung im Riss/Würm Interglazial (Eem) und Frühwürm (Sauerstoffisotopenstufe 6-3) in den Ostalpen. Mitteilungen der Kommission für Quartärforschung an der Österreichischen Akademie der Wissenschaften 12:39-92.

Drescher-Schneider R, Jacquat C, Schoch W. 2007. Palaeobotanical investigations at the mammoth site of Niederweningen (Kanton Zürich), Switzerland. Quaternary International 164-165:113-29.

Fankhauser A, McDermott F, Fleitmann D. 2016. Episodic speleothem deposition tracks the terrestrial impact of millennial-scale last glacial climate variability in SW Ireland. Quaternary Science Reviews 152:104-17.

Fernández-Mosquera D, Vila-Taboada M, Grandald'Anglade A. 2001. Stable isotopes data $\left(\delta^{13} \mathrm{C}\right.$, $\delta^{15} \mathrm{~N}$ ) from the cave bear (Ursus spelaeus): a new approach to its palaeoenvironment and dormancy. Proceedings of the Royal Society London B 268: 1159-64.

Frischauf C, Krutter S, Rabeder G. 2015. Die fossile Höhlenfauna der Bärenfalle im Tennengebirge. In: Krutter S, Schröder F, editors. Durch die Schichten der Zeit! Neue Erkenntnisse zwischen Mesozoikum und Gegenwart. Forschungen des Museums Burg Golling 1:33-44.

Genty D, Blamart D, Ouahdi R, Gilmour M, Baker A, Jouzel J, Van-Exter S. 2003. Precise dating of Dansgaard-Oeschger climate oscillations in western Europe from stalagmite data. Nature 421:833-7.

Heiri O, Koinig KA, Spötl C, Barrett S, Brauer A, Drescher-Schneider R, Gaar D, Ivy-Ochs S, Kerschner H, Luetscher M, Moran A, Nicolussi K, Preusser F, Schmidt R, Schoeneich P, Schwörer C, Sprafke T, Terhorst B, Tinner W. 2014. Palaeoclimate records $60-8 \mathrm{ka}$ in the Austrian and Swiss 
Alps and their forelands. Quaternary Science Reviews 106:186-205.

Hofreiter M, Rabeder G, Jaenicke-Després V, Withalm G, Nagel D, Paunovic M, Jambresic G, Pääbo S. 2004. Evidence for reproductive isolation between cave bear populations. Current Biology 14:40-3.

Hofreiter M, Capelli C, Krings M, Waits L, Conard N, Münzel S, Rabeder G, Nagel D, Paunovic M, Jambresic G, Meyer S, Weiss G, Pääbo S. 2002. Ancient DNA analyses reveal high mitochondrial DNA sequence diversity and parallel morphological evolution of late Pleistocene cave bears. Molecular Biology and Evolution 19:1244-50.

Horacek M, Frischauf C, Pacher M, Rabeder G. 2012. Stable isotopic analyses of cave bear bones from the Conturines Cave $(2,800 \mathrm{~m}$, South Tyrol, Italy). Braunschweiger Naturkundliche Schriften 11:49-54.

Jost-Stauffer M, Coope GR, Schlüchter C. 2005. Environmental and climatic reconstructions during Marine Oxygen Isotope Stage 3 from Gossau, Swiss Midlands, based on coleopteran assemblages. Boreas 34:53-60.

Krajcarz M, Pacher M, Krajcarz MT, Laughlan L, Rabeder G, Sabol M, Wojtal P, Bocherens H. 2016. Isotopic variability of cave bears $\left(\delta^{15} \mathrm{~N}\right.$, $\delta^{13} \mathrm{C}$ ) across Europe during MIS 3. Quaternary Science Reviews 131:51-72.

Leitner-Wild E, Steffan I. 1993. Uranium-series dating of fossil bones from alpine caves. Archaeometry 35:137-46.

Leitner-Wild E, Rabeder G, Steffan I. 1994. Determination of the evolutionary mode of Austrian alpine cave bears by uranium series dating. Historical Biology 7:97-104.

Lewis SG, Maddy D, Buckingham C, Coope GR, Field MH, Keen DH, Pike AWG, Roe DA, Scaife RG, Scott K. 2006. Pleistocene fluvial sediments, palaeontology and archaeology of the upper River Thames at Latton, Wiltshire, England. Journal of Quaternary Science 21:181-205.

Moseley GE, Spötl C, Cheng H, Svennson A, Brandstätter S, Edwards RL. 2014. Multispeleothem record reveals tightly coupled climate between Central Europe and Greenland during MIS 3. Geology 42:1043-6.

Müller UC, Pross J, Bibus E. 2003. Vegetation response to rapid change in central Europe during the past 140,000 $\mathrm{yr}$ based on evidence from the Füramoos pollen record. Quaternary Research 59:235-45.

Nigst PR, Haesaerts P, Damblon F, Frank-Fellner C, Mallol C, Viola B, Götzinger M, Niven L, Trnka G, Hublin J-J. 2014. Early modern human settlement of Europe north of the Alps occurred 43,500 years ago in a cold steppe-type environment. PNAS 111:14394-9.

Pacher M, Stuart AJ. 2009. Extinction chronology and palaeobiology of the cave bear (Ursus spelaeus). Boreas 38:189-206.
Peer T. 1980. Karte der aktuellen Vegetation Südtirols 1/100 000 Blatt Bozen. Documents de Cartographie ecologique 23:25-46.

Pike AWG, Hedges REM, van Calsteren P. 2002. U-series dating of bone using the diffusionadsorption model. Geochimica et Cosmochimica Acta 66:4273-86.

Pike AWG, Eggins S, Grün R, Hedges REM, Jocobi RM. 2005. U-series dating of the Late Pleistocene mammalian fauna from Wood Quarry (Steetley), Nottinghamshire, UK. Journal of Quaternary Science 20:59-65.

Preusser F. 2004. Towards a chronology of the Late Pleistocene in the northern Alpine foreland. Boreas 33:195-210.

Rabeder G. 1991. Die Höhlenbären der Conturines. Entdeckung und Erforschung einer DolomitenHöhle in $2800 \mathrm{~m}$ Höhe. Bozen: Athesia.

Rabeder G, Hofreiter M, Nagel D, Withalm G. 2004. New taxa of alpine cave bears (Ursidae, Carnivora). Cahiers scientifiques 2:49-67.

Rabeder G, Hofreiter M, Wild EM. 2005. Die Bären der Brieglersberghöhle (1625/24). Die Höhle 56:36-43.

Rabeder G, Debeljak I, Hofreiter M, Withalm G. 2008. Morphological responses of cave bears (Ursus spelaeus group) to high-alpine habitats. Die Höhle 59:59-72.

Rabeder G, Frischauf C. 2016. Fossile Bären in Höhlen. In: Spötl C, Plan L, Christian E, editors. Höhlen und Karst in Österreich. Linz: Oberösterreichisches Landesmuseum. p 183-98.

Rosendahl W, Döppes D, Kempe S. 2007. MIS 5 to MIS 8 - numerically dated palaeontological cave sites of Central Europe. In: Sirocko F, Claussen M, Litt T, Sánchez-Goñi MF, editors. The Climate of Past Interglacials. Developments in Quaternary Science Series 7:455-70.

Sambridge M, Grün R, Eggins S. 2012. U-series dating of bone in an open system: the diffusionadsorption-decay model. Quaternary Geochrono$\log y$ 9:42-53.

Slota PJ Jr, Jull AJT, Linick TW, Toolin LJ. 1987. Preparation of small samples for ${ }^{14} \mathrm{C}$ accelerator targets by catalytic reduction of $\mathrm{CO}$. Radiocarbon 29(2):303-6.

Spötl C, Mangini A, Richards DA. 2006. Chronology and paleoenvironment of Marine Isotope Stage 3 from two high-elevation speleothems, Austrian Alps. Quaternary Science Reviews 25:1127-36.

Spötl C, Reimer PJ., Rabeder G, Scholz D. 2014. Presence of cave bears in western Austria before the onset of the Last Glacial Maximum: new radiocarbon dates and palaeoclimatic considerations. Journal of Quaternary Science 29:760-6.

Starnberger R, Drescher-Schneider R, Reitner J, Rodnight H, Reimer PJ, Spötl C. 2013. Late Pleistocene climate change and landscape dynamics in the Eastern Alps: the inner-alpine Unterangerberg record (Austria). Quaternary Science Reviews 68:17-42. 
Stuiver M, Polach HA. 1977. Discussion: reporting of ${ }^{14}$ C data. Radiocarbon 19(3):355-63.

Svensson A, Andersen KK, Bigler M, Clausen HB, Dahl-Jensen D, Davies SM, Johnsen SJ, Muscheler R, Parrenin F, Rasmussen SO, Röthlisberger R, Seierstad I, Steffensen JP, Vinther BM. 2008. A 60000 year Greenland stratigraphic ice core chronology. Climate of the Past 4:47-57.

Terhorst B, Thiel C, Peticzka R, Sprafke T, Frechen M, Fladerer FA, Roetzel R, Neugebauer-Maresch C. 2011. Casting new light on the chronology of the loess/paleosol sequences in Lower Austria. $E \& G$ Quaternary Science Journal 60:270-7.

Thiel C, Terhorst B, Jaburová I, Baylaert J-P, Murray AS, Fladerer FA, Damm B, Frechen M, Ottner F. 2011. Sedimentation and erosion processes in Middle to Late Pleistocene sequences exposed in the brickyard of Langenlois/Lower Austria. Geomorphology 135:295-307.
Tütken T, Furrer H, Vennemann TW. 2007. Stable isotope compositions of mammoth teeth from Niederweningen, Switzerland: implications for the Late Pleistocene climate, environment, and diet. Quaternary International 164-165:139-50.

van der Plicht J, Palstra SWL. 2016. Radiocarbon and mammoth bones: what's in a date. Quaternary International 406:246-51.

van Klinken GJ. 1999. Bone collagen quality indicators for palaeodietry and radiocarbon measurements. Journal of Archaeological Science 26:687-95.

Wohlfarth B, Veres K, Ampel L, Lacourse T, Blaauw M, Preusser F, Andrieu-Ponel V, Kéravis D, Lallier-Vergès E, Björck S, Davies SD, de Beaulieu J-L, Risberg J, Hormes A, Kasper HU, Possnert G, Reille M, Thouveny N, Zander A. 2008. Rapid ecosystem response to abrupt climate change during the last glacial period in western Europe, 40-16 ka. Geology 36:407-10. 